\title{
Voorstellings van Batseba: Intertekstualiteit in literêre kuns, beeldende kuns en werklikheid
}

\author{
L C Bezuidenhout \\ Departement Bybelkunde (Afd A) \\ Universiteit van Pretoria
}

\begin{abstract}
Representations of Bathsheba: Intextuality in literary art, the visual arts and reality

Interesting parallels between literary and visual arts exist. A text may possess visuality, while visual arts may possess textuality. In this paper, the interrelations between the literary description of the story of David and Bathsheba (2 Sm 11) and depictions of this story in the visual arts are explored. For some reason, this story possesses exceptional creative potential. Particular attention is given to the painting 'The Toilet of Bathsheba (1654)' by Rembrandt. An analysis of this painting sheds light on the subtle dynamics of the story. Its haunting beauty succeeds in communicating the complex implications of the story. Sexuality serves as an interface between the story and reality, luring the reader into this intrigue. The reader finds himself unexpectedly in David's position. By acknowledging this kind of intertextuality, new dimensions of meaning can be explored.
\end{abstract}

\section{1. 'N PAAR TEORETIESE OORWEGINGS}

Dit is populêr om vanuit nuwe hoeke na die Bybelse teks te kyk. Tegnieke vanuit ander wetenskappe word dikwels ingespan om iets nuuts of iets anders oor die Bybel te sê. In hierdie artikel word die verwantskap tussen literatuur en visuele kuns ondersoek. Is dit moontlk dat jukstaposisie van verbale en visuele 'tekste' nuwe insigte kan oplewer en bruikbare strategieë kan bied ten opsigte van interpretasie?

Dit is veelseggend dat Mieke Bal hierdie oortuiging handhaaf (vgl Bal 1991:5). Toe sy vir 1987 'n leerstoel aangebied is in literatuurteorie aan die University of Toronto, het sy besluit om op Rembrandt te konsentreer. 'n Interessante publikasie het hieruit voortgespruit met die titel Reading Rembrandt: Beyond the word-image opposition (1991) waarin strategieë vanuit die literatuurteorie op beeldende kuns toegepas word en strategieë uit kunswaardering op tekste toegepas word. Dirk van den Berg het 'n insiggewende artikel gepubliseer met die titel 'Pictorial textuality: Imaginative reading of pictures'. In hierdie artikel wys hy ook op die raakvlakke tussen hierdie dissiplines (Van den Berg 1995:108-135). 
In die artikel wat hier volg, word nie gekompeteer met bogenoemde publikasies nie. Hier word nie 'n teoretiese onderbou gegee vir die integrasie van dissiplines nie. Die doel van hierdie artikel is om die literêre tradisies en visuele tradisies met mekaar in verband te bring om sodoende die profiel van die ontwikkeling van 'n tradisie oor grense heen te bestudeer.

In hierdie studie word van die veronderstelling uitgegaan dat kuns nie onskdig is, noodwndig is of sonder konsekwensies is nie (vgl Bal 1991:5). Of dit literêre kuns of visuele kuns is - alles in 'n 'teks' moet geïnterpreteer word. Daar mag geredeneer word dat sommige besonderhede geen narratiewe funksie het nie, maar dat dit net gebruik word om 'n effek van realisme te skep (Bal 1991:12; vgl Barthes 1968:84-89). Tog dra alles in ' $n$ kunswerk by tot die betekenis daarvan of modifiseer die betekenis (Bal 1991:12). Dit beteken nie dat alles saamwerk om 'n eenheid te bewerkstellig nie. Gegewens wat 'nie pas nie', word des te meer interessant.

In hierdie artikel word die klem gelê op respons. Kunswerke is deel van die respons op 'n tradisie. Die bestudering van die kunswerke kan nie aanspraak maak op absolute objektiwiteit nie - dit is ook maar respons op die kunswerke.

Konteks is ' $n$ belangrike element in die proses van interpretasie. Dit sal egter verkeerd wees om te beweer dat konteks 'n vaste en objektiewe vertrekpunt bied vir die interpretasie van tekste en kunswerke. Culler is reg as hy sê dat 'n konteks steeds 'n teks is wat geïnterpreteer moet word. ' $n$ Nuttige alternatief vir die vasstelling van konteks as vertrekpunt, is die konsep van 'raming'. Volgens Culler het waardering te doen met tekens, vorms en sosiaal-bepaalde betekenisse. Tekens word geraam (gekonstitueer) deur verskeie diskursiewe praktyke, institusionele ordeninge, waardestelsels en semiotiese meganismes. In waardering word die maniere waarop betekenis geraam word, bestudeer (Culler 1988:xiv).

\section{ALGEMENE OORSIG OOR LITERÊRE TRADISIES}

Die boeke 2 Samuel 11-12 en 1 Konings 1-2 vertel die verhaal van Batseba. Sy is die voorwerp van Dawid se begeertes en word opgeroep om gemeenskap met hom te hê. Het Batseba vir Dawid uitgelok? Sy word swanger - was dit deel van haar beplanning of is dit die onvoorsiene gevolge van Dawid se sonde? Dawid probeer om haar man oor te haal om by haar te slaap, sodat die indruk geskep word dat haar man die vader is van die ongebore kind - of is dit 'n lokval wat vir Uria gestel word om hom om die lewe te bring? Wanneer Dawid se plan sy loop neem, laat hy die man ombring en word Dawid self die vrou se man. Of was dit van die begin die doel wat Batseba wou bereik? God laat die baba sterf.

In 2 Samuel 11 speel Batseba 'n passiewe rol en geen melding word van haar emosies gemaak nie. Al wat sy in die hele episode doen, is om te sê 'ek is swanger' (2 
Sam 11:5). Selfs wanneer dit vermeld word dat sy oor haar man treur, is die leser nie seker of sy emosioneel betrokke is en of sy net die gebruike respekteer nie. In 2 Samuel 12:24 word dit gesê dat Dawid Batseba getroos het na die dood van haar seun. Hier erken die verteller Batseba se emosies. Tog word sy as karakter deur die verteller misken, sy is 'n 'non-person' (vgl Berlin 1982:72-73). In 1 Konings 1 tree sy op met moed en maak seker dat haar seun Salomo koning sal word. Daar kan maar net gespekuleer word oor die verhouding tussen Batseba en Abisag uit Sunem. Dit moes waarskynlik vernederend wees vir Batseba om te aanvaar dat Abisag sommige van haar funksies oorgeneem het.

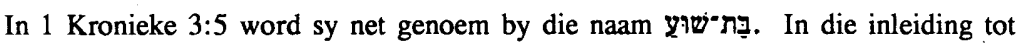
Psalm 51:1-2 word daar na haar verwys as die vrou met wie Dawid owerspel gepleeg het: "' $\mathrm{P}$ Psalm van Dawid, na aanleiding daarvan dat die profeet Natan na hom toe gekom het oor sy owerspel met Batseba'. In die Nuwe Testament word Batseba se naam nie genoem nie. Daar word in Matteus 1:6 na haar verwys as die vrou van Uria. Hier is sy deel van die geslagsregister van Jesus.

Volgens Joodse tradisie was Batseba van die begin af bedoel om Dawid se vrou te wees. Toe Uria Goliat se mondering na sy dood verwyder het, het hy aangedring op 'n Joodse vrou. Dawid het Batseba vir hom belowe. Dawid sou baie ly oor hierdie ondeurdagte besluit van hom. Dawid het eendag gevra waarom daar gepraat word van die God van Abraham, Isak en Jakob, maar nooit van die God van Dawid nie. God het hom geantwoord dat daar so na Hom verwys word omdat Abraham, Isak en Jakob getoets is, maar Dawid is nie getoets nie. God het ingestem om Dawid te toets, maar het Dawid voor die tyd gewaarsku dat hy nie die toets sal slaag nie. Na die toets het Dawid vir twee-en-twintig jaar lank boete gedoen ( Bührer 1994:189).

In Joodse sirkels is die owerspel van Dawid en Batseba geïnterpreteer as 'n gebeurtenis wat noodsaaklik was om vir die mense ' $n$ voorbeeld van berou te gee. Die klem is nie op die sonde self nie, maar op Dawid se reaksie op die sonde (KunothLeifels 1962:49-50). Die rol van die Satan of die duiwel word beskryf in 'n Joodse legende sowel as in 'n Persies-Schiïtiese legende. In die Joodse legende verskyn die Satan aan Dawid in die vorm van 'n voël. Dawid het 'n pyl na hom gegooi. Die pyl het hom nie getref nie, maar het 'n skerm van wilgertakke getref. Agter die skerm was Batseba besig om haar hare te kam. Dit het Dawid se begeerte gewek (Bührer 1994: 189). In die Persiese legende het die demoon Iblis Dawid onderbreek in sy gebed. Hy het 'n voël gevolg wat gevlieg het na die dak van Uria waar hy Batseba gesien het (Bührer 1994:191). 
In vroeë Christelike literatuur is die verhaal tipologies geïnterpreteer. In die Sacra Parallela van die agtste eeu (volgens tradisie afkomstig van Johannes van Damaskus) is 'n moralistiese interpretasie gegee. Batseba word beskryf as 'n voorbeeld van Christelike berou. Sy word vergewe deur God. In die Weste is sy gesien as 'n simbool van die kerk, soos gesien kan word in die geskrifte van Augustinus (Contra Faustum Manichaeum), Isodor von Sevilla en in die Bible Moralisée van die dertiende eeu. Dawid is gesien as 'n tipe van Christus en Batseba as 'n tipe van die kerk. Batseba se bad is 'n simbool van die Christelike doop (Bocian 1989:69). Uria simboliseer die Duiwel wat oorwin moet word. Die kroning van Batseba stel die kroning van die Maagd voor (in Biblia Pauperum in die dertiende en veertiende eeu). Dawid word soms gebruik as 'n voorbeeld van die misbruik van mag (Kunoth-Leifels 1962:49-50).

Die verhaal van Dawid en Batseba kom ook in die Koran voor. In Sura 38 word Natan se gelykenis van 2 Samuel 12 vertel (Bührer 1994:190).

Daar is heelwat Middeleeuse dramas oor Dawid, maar Batseba word selde vermeld. In 1556 het Hans Sachs die dramatiese kwaliteit van die Batseba-episode ontgin in sy Comedi David mit Bathsheba. In die laat sestiende tot agtiende eeu was die verhaal van Batseba gewild onder skrywers. Hulle het Dawid se boetedoening en onderwerping aan God se wil beklemtoon. In die twintigste eeu is die verhaal van Dawid en Batseba op verskeie maniere getransformeer in literatuur en drama (Bührer 1994:192193).

\section{HISTORIESE OORSIG OOR VISUELE UITBEELDINGS VAN DIE VER- HAAL VAN BATSEBA}

Visuele uitbeeldings van Batseba het verskillende doele gedien. In sommige uitbeeldings is sy met waardigheid uitgebeeld om aan te sluit by die respek wat aan haar in die tradisie betoon is. In 'n skildery deur Bernardo Strozzi (1581-1644) word haar moed uitgebeeld waar sy Dawid oorreed om haar seun Salomo as koning te kroon (vgl Bührer 1994:193). Die voorstelling van Batseba as 'n gesiene persoon in die hof van Dawid vind weerklank in 'n illustrasie uit Rudolf von Ems se Wêreld Kroniek, fol. 97r in die veertiende eeu. Aan die bokant van die prent buig Batseba oor Dawid waar hy sterwend op sy bed lê. In die onderste gedeelte staan sy agter Natan waar hy die oop graf van Dawid seën. In albei gevalle dra sy 'n kroon (vgl. Bührer 1994:193).

Die vrouefiguur tussen Dawid en Salomo is waarskynlik Batseba wat as een van die voorouers van Jesus uitgebeeld word in die Portail Royal in Chartres (c 1145-70; vgl Kunoth-Leifels 1962:50).

Die klem wat soms in die literatuur gelê word op die berou van Dawid, vind weerklank in visuele uitbeeldings, soos in 'n skets van Rembrandt (1606-1669) waar Natan 
Dawid betig en die illustrasie van Dawid wat berou het in die Boek van die Ure van die Hertog van Berry, geskep deur die broers Limbourg in die begin van die vyftiende eeu (vgl Bührer 1994:192). Dit is egter die toneel van 'verleiding' wat die meeste aandag kry in die visuele kuns. In die literatuur word geen aanduiding gegee van Batseba se motiewe of emosies nie. Hierdie vakuum is deur kunstenaars aangegryp en betekenis daaraan gegee.

Die toneel van die bad word vir die eerste keer teëgekom in 'n illustrasie van die Bisantynse manuskrip van Sacra Parallela van Johannes van Damaskus (vlg die tradisie) uit die negende eeu. In hierdie illustrasie staan Dawid op 'n balkon. Onder kan Batseba en 'n diensmeisie gesien word (Kunoth-Leifels 1962:50). Al word 'n diensmeisie nie in die Ou Testament genoem nie, kom een of meer diensmeisies in byna al die uitbeeldings van die bad voor. In die dertiende eeu is twee ander elemente bygevoeg, naamlik 'n boodskapper wat Dawid se boodskap oordra en 'n nuwe omgewing waarin die badtoneel plaasvind. Dit vind nie meer in 'n bad plaas nie, maar in 'n stroom in 'n pragtige tuin (vgl Die Bybel van St. Louis). Hierdie elemente konstitueer die ikonografiese skema wat in die volgende jare gebruik sou word. Variasies is geskep deur die keuse van ander momente in die verhaal, deur die manier waarop die badtoneel plaasvind (afhangende van die gebruike van die tyd) die verandering van die agtergrond of die manier waarop die vrou reageer op die uitnodiging. Die motief van die kunstenaar is ook baie belangrik: Is hy geïnteresseerd in die dramatiese kwaliteit van die verhaal, of is die uitbeelding van 'n naakfiguur sy primêre doel (vgl KunothLeifels 1962:50)?

In 'n miniatuur uitbeelding van die Codex Germanicus 206 van Augsburg (ca 1457), staan Dawid langs Batseba en bewonder haar terwyl sy besig om in 'n badjie te bad. Hy het heelwaarskynlik van die paleis afgekom om haar van naby te bekyk (fig 1; vgl Bührer 1994:184). Volgens hierdie uitbeelding gebruik Dawid die inisiatief om haar te sien. Sy word nie sensueel voorgestel nie. In 'n illustrasie uit die Bible
Figuur 1: Natekening uit Codex Germanicus

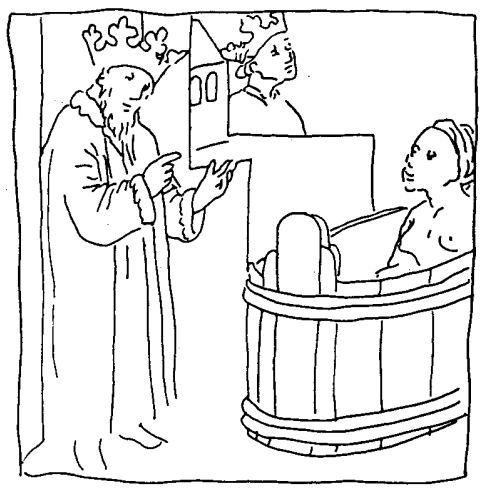


Figuur 2: Natekening uit Bible Mora-

lisée

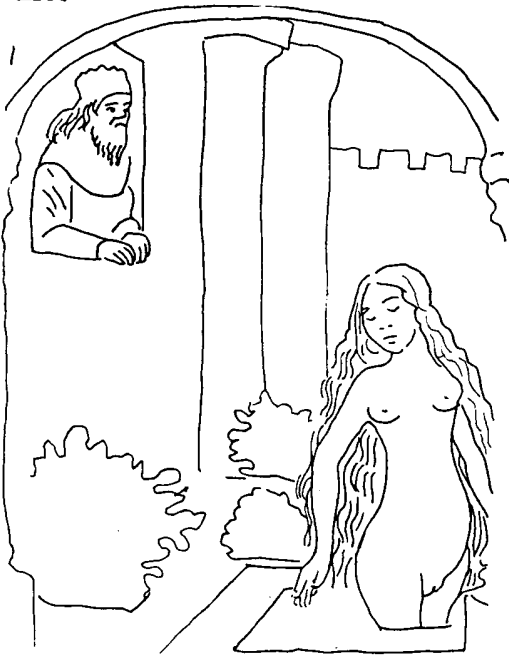

Hans Memling (1440-1490) het Batseba uitgebeeld waar sy die bad verlaat in 'n huis. Sy word onmiddellik deur 'n bediende toegedraai. Ver in die agtergrond staan Dawid op ' $n$ balkon en kyk na haar. Volgens hierdie uitbeelding sou dit vir Dawid moeilik wees om haar liggaam te sien. Sy en haar bediende doen hulle bes dat sy nie gesien word nie. In hierdie uitbeelding, moet Dawid geblameer word (fig 3, vgl Bührer 1994:189).
Moralisée (15e eeu, Codex Vindobonesis 166, fol 76), is Dawid besig om na Batseba te staar, terwyl sy in 'n poel water bad (fig 2, vgl Bührer 1994: 187). Die manlike leser sal waarskynlik met Dawid simpatie hê. Alhoewel dit nie ' $\mathrm{n}$ besonder kunstige uitbeelding is nie, word daar tog klem gelê op die sensualiteit van Baseba. Dawid lyk soos 'n toevallige toeskouer.

Figuur 3: Natekening van 'n skildery van Hans Memling

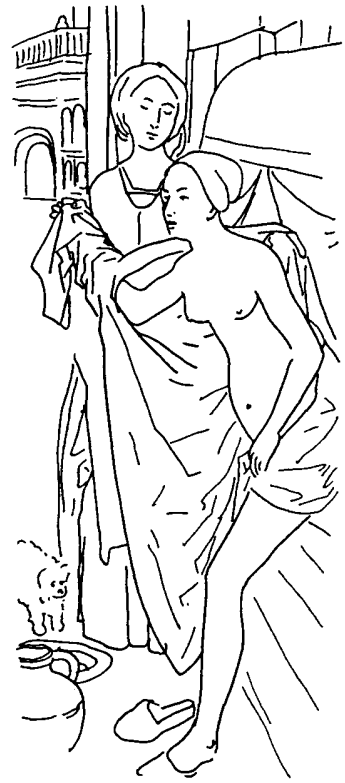


Dürer het in 1549-1551 'Batseba in die bad' en 'Dawid verraai Uria' geskilder met die oog op die dekorasie van die stadsaal in Nümberg. Die kunstenaar se doel was om te waarsku teen die misbruik van mag (Bocian 1989:70).

In 'n skildery van Wolfgang Krodel (1528-1555) staan Dawid op sy balkon en speel harp vir Batseba en haar twee vriendinne. Batseba en haar vriendinne is geklee in 'n komtemporêre styl. ' $n$ Bediende was Batseba se voete in 'n stroom (fig 4; vgl Bührer 1994:286). Volgens hierdie uitbeelding is die toneel redelik onskuldig, maar Dawid neem die inisiatief om Batseba te beïndruk.

\section{Figuur 4: Natekening van 'n skildery van Wolfgang Krodel}

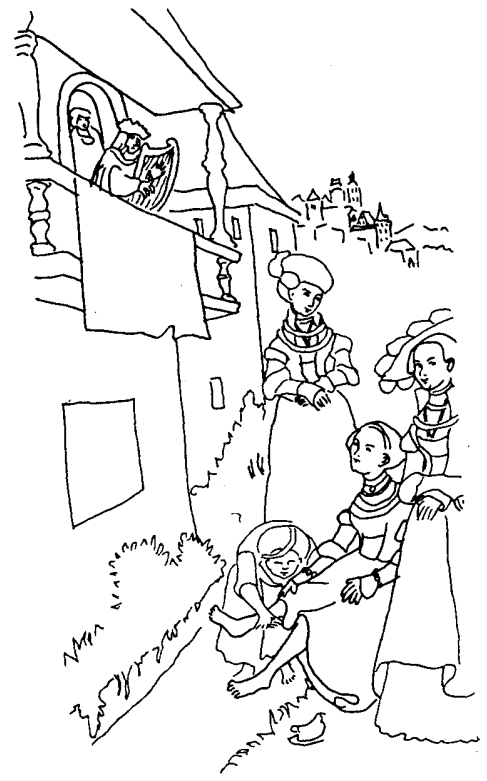

In 'n houtsneewerk van Lucas Cranach die Ouere (1524) word Batseba se voete gewas deur 'n bediende. 'Batseba en haar drie vriendinne is oordadig aangetrek. Batseba se rok is tot net bokant haar knieë opgetrek (vgl Bührer 1994:188). In die Duitse Renaissance was dit gewild om Batseba uit te beeld waar sy net haar voete was. Dit hou waarskynlik verband met die vertaling van Luther wat verwys na 'was' en nie 'bad' nie (Kunoth-Leifels 1962:51).

Van die sestiende eeu af word Batseba se psigologiese reaksie in haar gesigsuitdrukking en lyftaal weerspieël. Batseba se liggaam is sowel die oorsaak as die slagoffer van die koning se wellus (Kunoth-Leifels 1962:51). 
In 'n skildery deur $C$ Cornelisz van Haarlem (1562-1638) is Batseba besig om naak te bad, maar sy dra juwele. Sy word gehelp deur twee bediendes, een wit en een swart. Die wit bediende is ook naak en staan met haar rug na die toeskouer. Die toneel vind plaas in 'n tuin (fig 5; vgl Bührer 1994:189).
Figuur 5: Natekening van 'n skildery van Cornelisz van Haarlem.

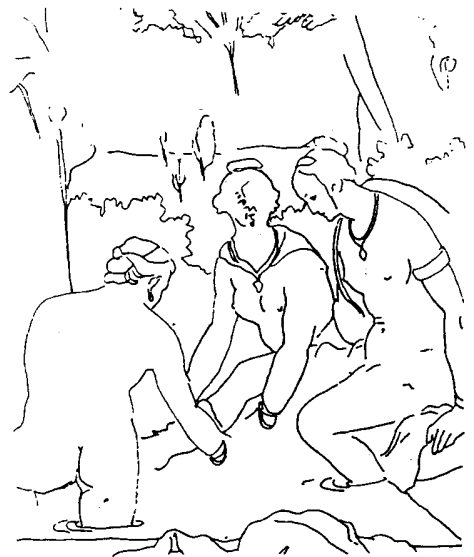

Alhoewel Batseba self nie uitlokkend uitgebeeld word nie, spreek die hele toneel van sensualiteit. Hier word die blaam nie op iemand spesifiek geplaas nie. Dit lyk asof die situasie aanleiding gegee het tot die probleem. Hans von Aachen (1552-1615) konsentreer op die skoonheid en ydelheid van Batseba. Hy skilder haar naak met 'n persoon wat 'n spieël langs haar vashou (vgl Bührer 1994:190). Dit is ironies dat manlike skilders 'n vrou se liggaam skilder vir die vreugde daarvan, 'n spieël daarby voeg en dit 'ydelheid' noem (vgl Berger 1980:51).

In 'n skildery deur Peter Paul Rubens (1577-1640) sit Batseba met haar bene en borste sigbaar vir die kyker. Sy hou pêrels in haar hand terwyl 'n diensmeisie haar hare kam. 'n Boodskapper bring Dawid se boodskap. In die agtergrond kyk Dawid van sy balkon af (fig 6; vgl Bührer 1994:190). Rubens verlustig hom in haar liggaam. Sy draai haar kop om Dawid se boodskap te ontvang met die uitdrukking van 'n slinkse vrou wie se plan gewerk het. Dit is net die swart boodskapper se gesigsuitdrukking wat enige aanduiding gee dat dit wat hier gebeur, nie gepas is nie.
Figuur 6: Natekening van 'n skildery van Rubens.

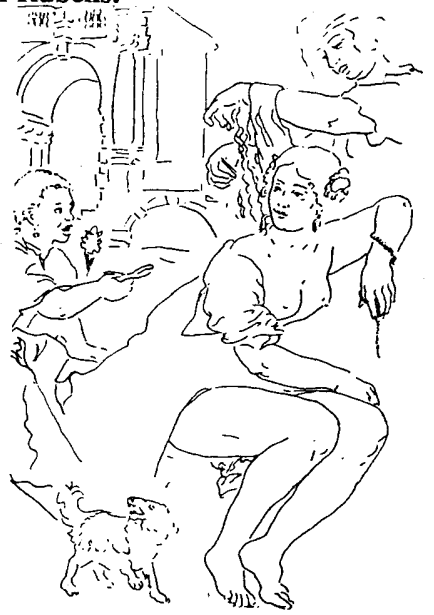

HTS 53/3 (1997) 
Rembrandt (1606-1669) het meer as een weergawe van Batseba geskilder. In een uitbeelding het hy haar naak geskilder na afloop van die bad. Een diensmeisie versorg haar voete en 'n ander kam haar hare. Batseba bedek een bors met haar hand (vgl Bührer 1994:191). Later in hier artikel word Rembrandt se skildery van 1654 in besonderhede bespreek.

Vanaf die sewentiende eeu is die uitbeelding van erotiese vroulike naaktheid prominent (Kunoth-Leifels 1962:51). In 'n skildery van Heinrich $F$ Fueger (1751-1818) sit Batseba halfnaak langs 'n stroom. Twee bediendes probeer om haar te af te skerm van toeskouers. Sy is egter nie so daaroor begaan nie en lees die boodskap van Dawid met belangstelling. Iemand hou 'n houer met juwele voor haar - waarskynlik 'n geskenk van Dawid (fig 7; vgl Bührer 1994:189).

\section{Figuur 7: Natekening van 'n skildery van Fueger.}

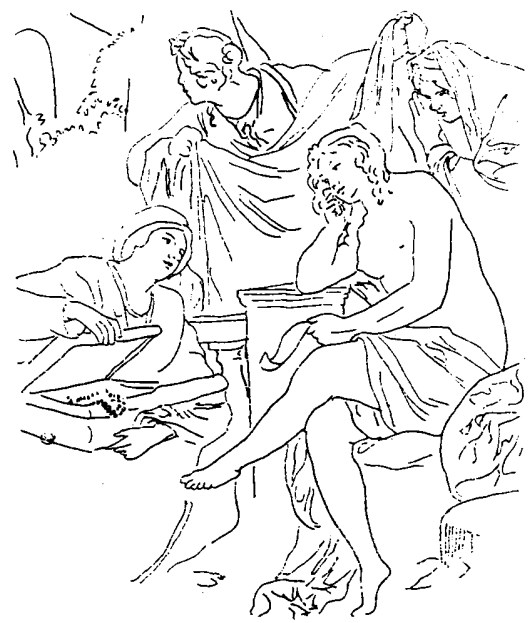

\section{WISSELWERKING TUSSEN VISUALITEIT EN TEKSTUALITEIT}

Word seksualiteit in die visuele kunste oorbeklemtoon in teenstelling met die literêre weergawe? Nee, in die literêre weergawe van die Troonopvolgingverhaal is seksuele sonde wat tot die dood lei, 'n sleutelmotief (vgl Blenkinsopp 1966:44-57) Carlson (1964:180) beskou dit as 'n organiserende beginsel. In die Dawid-Batseba-verhaal word owerspel gepleeg, in die Amnon-Tamar episode is dit verkragting en in die Absalom-byvrou episode die ontering van die vader se bed. Hierdie oortredings korrespondeer met die gebooie in Deuteronomium 22:22-30. Die belangstelling in die seksuele in die visuele kuns korrespondeer met 'n soortgelyke tendens in die literêre weergawe.

In visuele uitbeeldings word Batseba soms as aandadig aan die sonde, soms as onskuldig voorgestel. Hierdie perspektief neem uiterste afmetings aan wanneer sy op 'n Switerse tapisserie uit 1522 (tans in die Zürich Museum) uitgebeeld word saam met Simson en Delila en Judit en Holofernes (Kunoth-Leifels 1962:53). 
Kunstenaars wat hulle verlustig in Batseba se sensualiteit, impliseer waarskynlik dat sy skuldig is aan die uitlokking van Dawid. Is dit waar? Was sy op enige manier skuldig aan die dood van haar man? In die literêre teks is daar 'n dubbelsinnigheid. In Joab se gesprek met die boodskapper (2 Sam 11:18-22) is daar 'n subtiele aanduiding dat Batseba by 'n komplot betrokke kan wees. Joab het voorsien dat Dawid na die dood van Uria mag verwys na 'n soortgelyke geval waar Abimeleg dood is toe 'n vrou vanaf die stadsmuur 'n maalklip op sy kop gegooi het (vgl Rig 9:50-53).

Die motief dat 'n vrou 'n man doodmaak, word in die verhaal ingedra. Die feit dat daar na hierdie insident verwys word, kan onskuldig wees maar dit kan ook suggereer dat Batseba iets met die dood van haar man te doen het.

Volgens Randall Bailey (1990:88) het Batseba 'n komplot gesmee om met Dawid te trou. In die verhaal word genoem dat sy haar na maandstonde haar reinigingsbad geneem het. Dit word volgens Bailey vermeld om aan te toon dat sy op haar vrugbaarste was. Sy het geweet dat gemeenskap waarskynlik swangerskap sou impliseer. Daar is egter ook ' $n$ ander verklaring. Dit kan vermeld word om te bevestig dat Batseba nie swanger was voordat Dawid met haar gemeenskap gehad het nie (Berlin 1982:80).

Miskien was die plan om Uria na Batseba te stuur, nie bedoel om Dawid se aandeel aan die swangerskap toe te smeer nie, maar dit kon 'n plan wees om Uria tot die dood te veroordeel. Indien Uria by sy vrou geslaap het, sou hy die 'soldate eed' verbreek het wat tot die dood kon lei. Dawid se vraag in 2 Samuel 11:7 suggereer dat dit nie

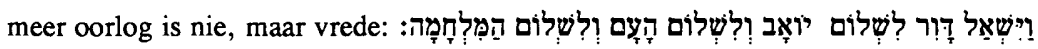

Aan die ander kan suggereer Uria se antwoord in vers 11 'n tyd van oorlog: ‘... terwyl die ark en Israel saam met Juda in hutte woon en my aanvoerder Joab sowel as $u$ soldate in die oop veld kamp opslaan ....' In vers 8 staan dat die koning 'n 'geskenk'

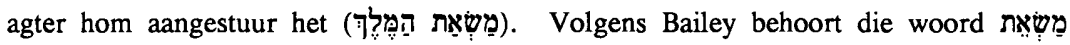
gelees word binne die konteks van 'n teken - iemand is gestuur om aan die koning 'n teken te gee wanneer Uria sy eed van onthouding verbreek (1990:96-98). Dit moet genoem word dat Cheryl Exum (1993:170-201) heftig reageer teen die stelling dat Batseba iets te doen gehad het met 'n set om met Dawid te trou.

In baie uitbeeldings speel die brief wat Batseba hou 'n belangrike rol. Dit kan beskou word as 'n aspek van of tekstualiteit in die skildery. Dit is vreemd dat hierdie element so volop is alhoewel dit nie eers in die Bybelse teks genoem is nie. In die Bybel vervul 'n brief 'n sleutelfunksie, maar dit is die brief wat na Joab gestuur is en gedra is deur Uria. Hierdie brief bevat Uria se doodvonnis. In die verhaal is hierdie 'n interessante, ironiese element. Al die hoofkarakters het op een of ander manier te doen met die brief. Dawid het dit geskryf, Uria het dit gedra en Joab het dit ontvang. 
Dawid is verantwoordelik vir die oortreding aangesien hy dit beplan het. Uria is verantwoordelik vir sy eie dood, aangesien hy nie vir Dawid toegelaat het om 'n alternatiewe oplossing te vind vir Batseba se dilemma nie. Indien Bailey se voorstel aanvaar word, is Uria tot die dood veroordeel, maar het hy sy eie manier van voltrekking gekies. In sy geval impliseer verantwoordelikheid nie skuld nie. Joab is verantwoordelik omdat hy doelbewus Uria se dood in die stryd bewerkstellig het. In die visuele kunste word hierdie brief ook uitgebeeld. Govaert Flinck (1615-1660) het die toneel geskilder waar Dawid aan die Uria die brief oorhandig (vgl Bührer 1994:192). Die koninklike sekretaris sit aan die teenoorgestelde kant van Dawid. In 'n skildery van Bronckhorst vervang Batseba die koninklike sekretaris. Word Batseba hierdeur geïmpliseer as medepligtige? Miskien is die suspisie teen Batseba die gevolg van die vermenging van die briewe in die verhaal. Die brief wat dawid aan Batseba stuur in die visuele kuns mag op een of ander manier vermeng wees met die brief wat Uria na Joab mes neem. Die feit dat Batseba ' $n$ brief in haar hand hou, mag in sommige skilderye 'n subtiele aanduiding wees dat sy betrokke is by die dood van haar man. Die tekstualiteit in die visuele kuns kan dieselfde funksie vervul as die visualiteit in die teks waar Joab die dood van Abimeleg gebruik as 'n parallel van die dood van Uria (vgl Bal 1991:238).

\section{5. 'n Waardering van Rembrandt se 'Versorging van Batseba' 1654 (Musée du Louvre)}

Hierdie skildery (fig 8) kan geïnterpreteer word vanuit verskillende hoeke. Dit kan ikonografies geïnterpreteer word as 'n voorstelling van die storie in die Hebreeuse Bybel. Dan is kennis van biografiese gegewens belangrik. Dit kan geïnterpreteer word as 'n tradisionele naakstudie, 'n voyeuristiese werk (Bal 1991:225). Dit is nie nodig om slegs een van die benaderings te kies nie, almal kan tegelykertyd funksioneer.
Figuur 8: Natekening van Rembrandt se 'Versorging van Batseba' van 1654.

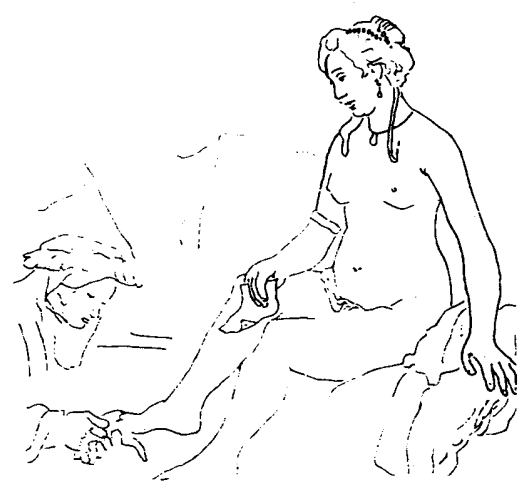


Die brief is ' $n$ interessante element van die skildery. Dit kan gesien word as ' $n$ element van 'n genre-skildery (vgl 'Dame wat ' $n$ brief lees by ' $n$ oop venster' - (Gemaldegalerie, Dresden) en 'Vrou in blou wat 'n brief lees', (Rijksmuseum, Amsterdam) deur Vermeer c. 1658). Tog het dit in hierdie skildery 'n besondere betekenis. Dit kan 'n voortsetting wees van die motief van 'n boodskapper wat Dawid se uitnodiging bring, soos dit dikwels in skilderye uitgebeeld word. Aan die ander kant kan 'n samesmelting van motiewe plaasvind. Die enigste brief wat in die verhaal vermeld is, is die brief wat Dawid aan Joab stuur. Daar is ' $n$ rooi kolletjie in die hoek van die brief. Dit kan 'n seël wees, maar dan sou dit waarskynlik in die middel van die papier wees. Volgens Bal, kan dit gesien word as 'n proleptiese teken van toekomstige geweld. Dit kan verwys na die geforseerde toe-eiening van Batseba deur Dawid, die gevolglike moord op haar man, en die dood van die kind wat gebore sou word (Bal 1991:229). Die feit dat Batseba die brief in haar hand hou, kan ' $n$ aanduiding wees dat ' $n$ aandeel in hierdie gebeure het.

Batseba se naaktheid en die versorging van die bediendes kan gesien word as die kunstenaar se konformering met 'n tradisie van uitbeelding. Dit stem ooreen met Tintoretto se uitbeelding van Susanna en die ouderlinge (Kunsthistorisches Museum, Wenen). Daar is ' $n$ interessante samesmelting van gebeure in die kunswerk. Die kunstenaar vertoon Batseba aan ons die oomblik toe sy die boodskap kry na die bad, maar hy wys haar ook soos sy gelyk het toe Dawid haar gesien het tydens die bad. Die brief kan ook dui op die dood van Uria. Die gebeure voor en na die dood van Uria is waarskynlik in hierdie skildery geïmpliseer.

Daar is ook ' $n$ interessante jukstaposisie van perspektiewe op Batseba. Die vrou se liggaam is effens na die kyker gedraai. Dit kan die indruk skep dat die vrou haar liggaam aan die voyeur bied - of dit die koning is of die persoon wat die skildery waardeer (vgl Bal 1991:227). Hierdie houding kan Batseba se skuld in die owerspel impliseer. Indien die persoon wat die skildery waardeer, 'n voyeuristiese benadering tot die skildery volg, gedra hy homself net soos Dawid. Vir die manlike kyker, is moeilik om die skoonheid van die vrou se liggaam nie te waardeer nie. Tog is daar onmiddellik 'n beperking wat die sensitiewe kyker verhoed om dit as 'n suiwer sensuele uitbeelding te interpreteer. In 'n uitbeelding wat bedoel is om die kyker te verlei, kyk die model gewoonlik met ' $n$ betekenisvolle uitdrukking na die kyker. Die uitdrukking op die gesig van Batseba beeld melancholie uit. Sy is in gedagte. Haar houding, veral die posisie van haar bene, is onnatuurlik. Dit lyk asof sy die kunstenaar se poging om haar liggaam in die rigting van die kyker te forseer, weerstaan. Hierdie verskynsel kom ooreen met die moderne feministiese lees van die storie. Hulle laat die karakter Batseba protesteer teen die verteller se manipulasie. 
Hierdie skildery maak sin op 'n biografiese vlak. Die skildery is geskilder in die jaar toe Hendrickje Stoffels opgeroep is om voor die kerkraad van die Nederduitsch Hervormde Kerk te verskyn op aanklag dat sy in sonde saam met Rembrandt woon (vgl Schwartz 1985:292). Die brief in Batseba se hand kan die boodskap wat Hendrickje Stoffels van die kerkraad gekry het, simboliseer. Miskien protesteer Rembrandt teen die aanslag op die integriteit van Hendrickje Stoffels.

\section{SLOTOPMERKING}

Is dit moontlik dat verskillende elemente van die chronologie van die verhaal so kan saamsmelt? Is dit moontlik dat daar so 'n samesmelting van kontekste kan plaasvind? Hierdie effek van gelyktydigheid is nie alleen 'n tegniek wat in visuele kunste gebruik word nie, maar in alle kunsvorme, selfs in literêre kuns.

Daar is 'n grenslose diversiteit in 'n teks. 'n Teks bied wel weerstand teen sekere interpretasies, maar dit open 'n hele spektrum van verstaansmoontlikhede. Betekenis word nie gekonstitueer deur die redusering van aspekte tot 'n eenheid nie. Dit is 'n verskraling van betekenis. In visuele kunste leer ' $n$ mens op kontra-stemme en kontrakontekste te waardeer.

Sommige van die verstaansmoontlikhede word sigbaar wanneer daar vanuit nuwe perspektiewe na die teks gekyk word. Tegnieke wat in ander dissiplines ontwikkel is, kan met vrug oor grense van dissiplines toegepas word. Alle vorms van kuns is immers 'n funksie van die mens. Dit impliseer dat daar gemeenskaplikhede tussen verskillende konsvorme kan wees wat estetiese norme en betekensgewende strukture aanbetref. Wanneer ' $n$ bepaalde tradisie ontwikkel oor die grense van kunsvorme, bied dit 'n uitstekende vertrekpunt om hierdie kunsvorme in dialoog met mekaar te laat kommunikeer.

\section{Literatuurverwysings}

Bal, M 1991. Reading Rembrandt: Beyond the word-image opposition. Cambridge: Cambridge University Press.

Bailey, R C 1990. David in love and war: The pursuit of power in 2 Samuel 10-12. Sheffield: JSOT Press. (JSOTSS.)

Barthes, R 1968. L'Effet de réel. Communications 4: 84-89. [English: The reality effect, in The rustle of language, tr by Richard Howard, 141-154. New York: Hill and Wang.]

Berger, J 1980. Ways of seeing. London: British Broadcasting Corporation and Penguin Books. 
Berlin, A 1982. Characterization in Biblical narrative: David's wives. JSOT 23, 6985.

Blenkinsopp, J 1966. Theme and motif in the succession history (2 Sam. Xi 2ff.) and the Yahwist Corpus. Vetus Testamentum Supplements 15, 44-57.

Bocian, M 1989. Lexicon der biblischen Personen. Stuttgart: Alfred Kröner Verlag.

Bührer, E (ed) 1994. Great women of the Bible in art and literature. Grand Rapids: Eerdmans.

Carlson, R A 1964. David, the chosen king: A traditio-historical approach to the Second Book of Samuel, tr by E J Sharpe \& S Rudman. Stockholm: Almquist \& Wiksell.

Culler, J 1988. Framing the sign: Criticism and its institutions. Norman, Oklahoma and London: University of Oklahoma Press.

Exum, C E 1993. Fragmented women: Feminist (sub)versions of Biblical narratives. Sheffield: JSOT Press. (JSOTSS.)

Goosen, L 1990. Van Abraham tot Zacharia: Thema's uit het Oude Testament in religie, beeldende kunst, literatuur, muziek en theater. Nijmegen: SUN.

Kirkwood, G M 1959. A short guide to classical mythology. New York: Holt, Rinehart and Winston.

Kunoth-Leifels 1962. Batseba, in Goosen 1990:49-53.

Mullins, E 1985. The painted witch: female body/male art. London: Secker \& Warburg.

Schwartz G 1985. Rembrandt: His life, his paintings. Harmondsworth: Penguin.

Van den Berg, D 1995. Picrorial textuality: Imaginative reading of pictures, in Nel $P$ $\mathrm{J}$, \& Van den Berg, D J (eds), Concepts of textuality and religious texts, 108-135. Bloemfontein: UOVS-SASOL Biblioteek. (Acta Academica Supplementum 1.) 